\title{
Correction to: Relational Violence, Social Support, Self-Esteem, Depression and Anxiety: A Moderated Mediation Model
}

Erdinç Duru' ${ }^{1}$ Murat Balkis ${ }^{1} \cdot$ Turgut Turkdoğan ${ }^{1}$

Published online: 2 August 2019

(c) Springer Science+Business Media, LLC, part of Springer Nature 2019

Correction to: Journal of Child and Family Studies (2019) https://doi.org/10.1007/s10826-019-01509-2

The original version of this article unfortunately contained a mistake. The spelling of one of the author's family name
Turkdoğan was incorrect. The letter "d" was missing. The original article has been corrected.

The original article can be found online at https://doi.org/10.1007/ s10826-019-01509-2.

Erdinç Duru

eduru@pau.edu.tr

1 Faculty of Education, Department of Psychological Counseling and Guidance, Pamukkale University, Kinikli, 20070 Denizli, Turkey 